\title{
EPSL
}

ELSEVIER

\section{Seismic wide-angle study of accreted Proterozoic crust in southeastern Wyoming}

\author{
Karsten Gohl ${ }^{1}$, Scott B. Smithson \\ Department of Geology and Geophysics, University of Wyoming, Laramie, WY 82071, USA
}

Received 24 March 1994; revision accepted 25 April 1994

\begin{abstract}
A seismic wide-angle experiment was conducted in southeastern Wyoming, USA to investigate the seismic character of a postulated Proterozoic magmatic arc south of the suture (Cheyenne Belt) to the Archean Wyoming Province. Recordings from vibrator and dynamite sources with offsets between 34 and $126 \mathrm{~km}$ reveal no evidence for Moho reflections. The large-offset recordings contain multicyclic bands of reflective phases from the middle to lower crust. The data were transformed into the intercept time-ray parameter $(\tau-p)$ domain to estimate local depth bounds. A subsequent 1D inversion using high-amplitude $\tau-p$ arrivals shows that the reflective part of the crust ranges from the depths of 25 to $40 \mathrm{~km}$. This part of the crust exhibits velocities increasing from about 6.5 to 7.5 $\mathrm{km} / \mathrm{s}$. Reflectivity modeling shows that the lower crust might consist of a zone of alternating low- and high-velocity layers with average velocity increasing. The average lower crustal velocity of about $6.9 \mathrm{~km} / \mathrm{s}$ suggests a predominantly mafic composition with interlayered intermediate to felsic components generating impedance contrasts that cause observable amplitudes from reflections at large offsets but not at clearly pre-critical and near-vertical distances. Our model is consistent with observations of interlayered sequences of gabbroic to ultramafic rocks with more felsic anorthositic and charnockitic rocks in the exposed lower crust of magmatic arc complexes. The lack of wide-angle Moho reflections might be explained by a gradational compositional boundary, or a transitional phase change from granulite to eclogite facies.
\end{abstract}

\section{Introduction}

The nature of the crust-mantle boundary and the crustal structure in different tectonic regimes is still an important problem. The boundary of the Archean Wyoming Province in the western United States is considered to be an accretionary

\footnotetext{
[PT]

${ }^{1}$ Now at the Alfred Wegener Institute for Polar and Marine Research, Postfach 120161, D-27515 Bremerhaven, Germany
}

feature of a collision between a Proterozoic island arc and the Archean terrane in southeastern Wyoming [1-6]. Questions that remain open include the structure and composition of the midcrustal and lower crustal rocks and the character of the crust-mantle boundary of the deep crust of the Proterozoic belt south of the suture (Cheyenne Belt). To address some of these questions, the University of Wyoming conducted several seismic wide-angle and normal-incidence reflection experiments in southeastern Wyoming. Here we present wide-angle data from vibroseis 
and dynamite shots recorded into receiver profiles located on the bedrock of the Laramie Range and the northern Colorado Front Range to obtain deep crustal velocity information and to search for high-amplitude critical reflections from the Moho. The seismic data also show the use of vibrators at long offsets in a favorable geologic environment.

\section{Geology and previous geophysical studies}

The most prominent geologic feature in southeastern Wyoming is the NE-SW striking Cheyenne Belt (Fig. 1), a major shear zone that bounds the Archean Wyoming Province to the north against the lithologically different Proterozoic terrane to the south $[3,4,5,7,8]$. 2700 to 2500 Ma old exposed basement in the Laramie Range, Medicine Bow Mountains and Sierra Madre con- sists of quartzofeldspathic gneisses, Archean supracrustal rocks, and late Archean intrusive granites. A sequence of quartz-rich metasedimentary rocks in the Medicine Bow Mountains is interpreted as rift deposits within an early Proterozoic basin along the southern margin of the Archean craton [9]. Proterozoic basement rocks south of the Cheyenne Belt are different in composition from rocks to the north. They consist of 1800-1600 Ma old highly deformed amphibolitegrade metavolcanic rocks. The existence of pillow basalts and agglomerates possibly indicates the presence of an early Proterozoic island arc [6]. Syn- and post-tectonic anorthositic and granitic intrusions, such as the Laramie anorthosite (1400-1500 Ma) and Sherman granite (1400 Ma) complexes $[1,10,11]$ cover areas on top and south of the Cheyenne Belt. Northward thrusting of an island arc over the northern craton as a consequence of S-dipping subduction is one model for
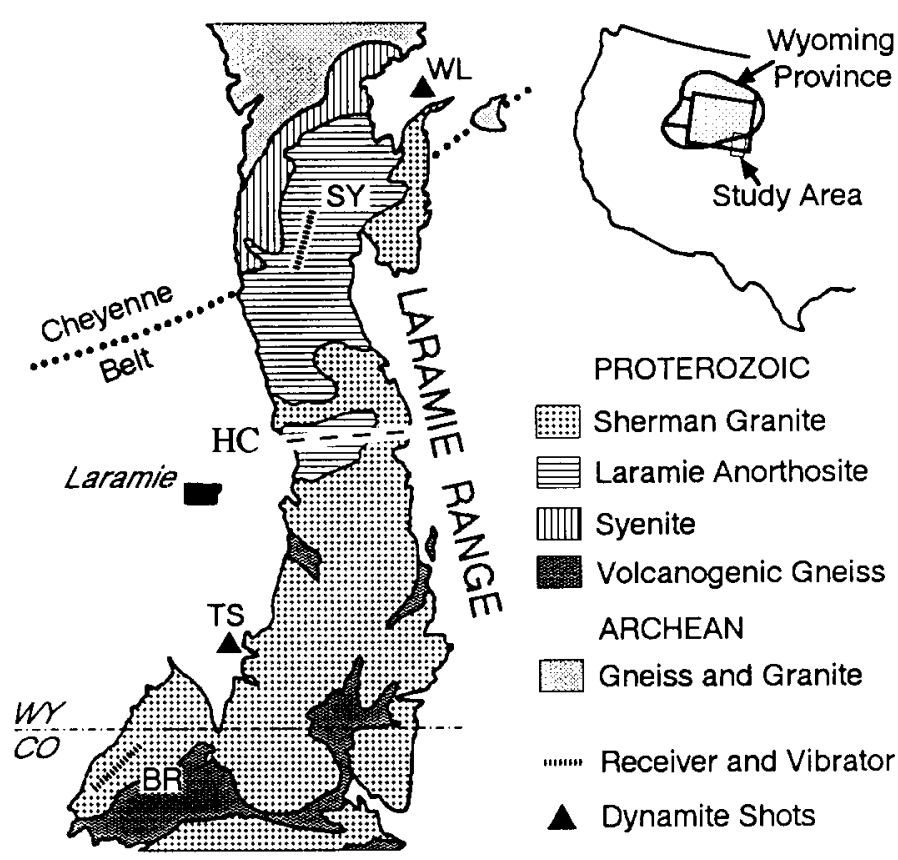

PROTEROZOIC

Sherman Granite

Laramie Anorthosite

IIIII Syenite

Volcanogenic Gneiss

ARCHEAN

Gneiss and Granite

....um Receiver and Vibrator Profiles

$\Delta$ Dynamite Shots

난 $\quad 10 \quad 20 \quad 30 \mathrm{~km}$

Fig. 1. Schematic map of geologic units in southeastern Wyoming including seismic wide-angle shot and receiver locations. Both wide-angle lines SY and BR served as reversed vibroseis shot and receiver profiles. The dynamite shots TS and WL were recorded on profile BR. The broken line across the Laramie Range indicates the location of the recently recorded CDP profile (HC) as described in [20]. 
the juxtaposition of the terranes [3,11]. A second model, based on isotopic data of Proterozoic granitoids in the Laramie Range, suggests a predominantly Proterozoic lower crust under the Cheyenne Belt, generated by magmatic underplating or underthrusting of Proterozoic crust during terrane accretion [12]. The large time difference of about 200-400 Ma between the formation of the metavolcanics and the emplacement of the granitic and anorthositic plutons, however, suggests an extended history of possibly several accretional events.

Widely spaced seismic refraction data indicate a crust that thickens from $37-41 \mathrm{~km}$ in southeast- ern Wyoming to about $48-54 \mathrm{~km}$ beneath the Colorado Front Range [13-15]. COCORP reflection profiles across the Laramie Range exhibit low-amplitude, discontinuous, multicyclic arrivals that are observed over the Denver and Laramie Basins [16,17]. These events were interpreted as possible Moho reflections arriving from depths of $48 \mathrm{~km}$ north of the Cheyenne Belt. Events in profiles south of the Cheyenne Belt were identified as possible Moho reflections from a depth of about $37-39 \mathrm{~km}$. Reanalyses of the COCORP data, however, suggest that the events interpreted as Moho reflections below the basins are likely to be due to strong reverberations within the sedi- receiver profile $\mathrm{SY} 87$

VP 22

\section{receiver profile $B R 87$}

$$
\text { VP } 143
$$

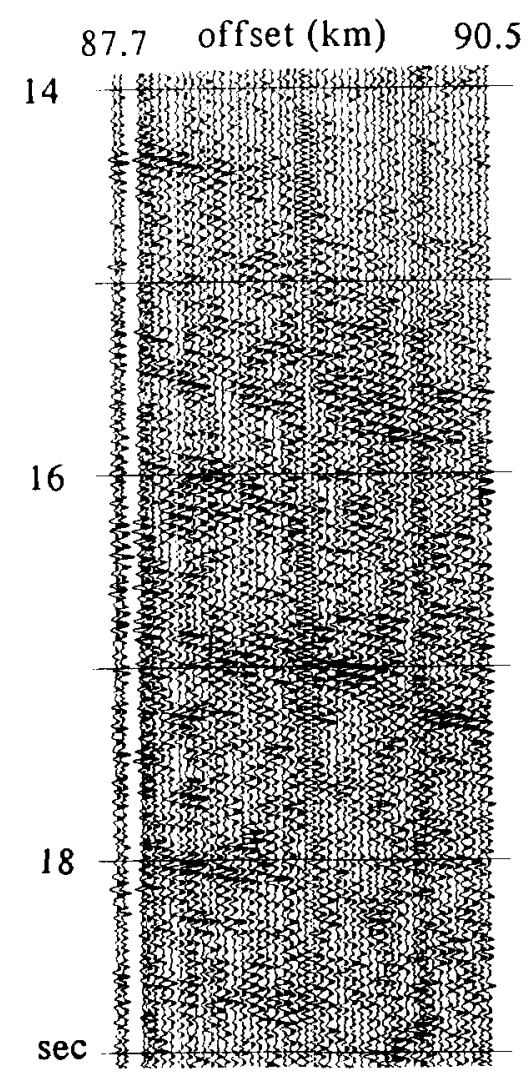

a

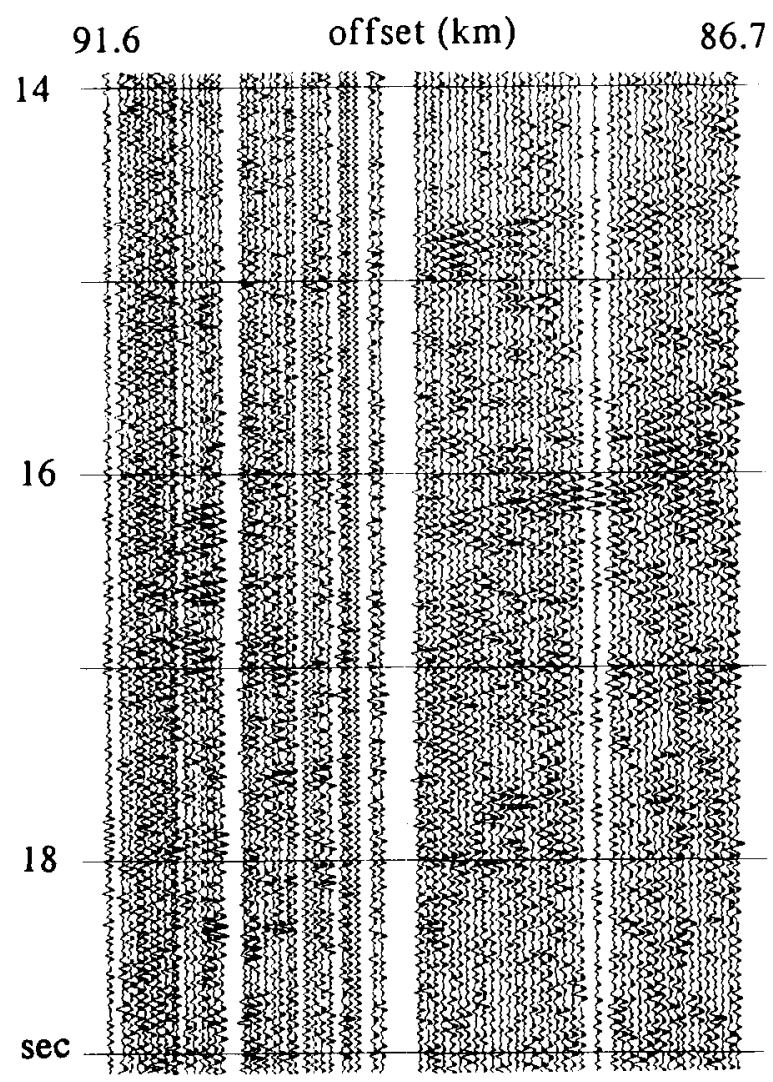

b

Fig. 2. Vibroseis records from receiver profiles (a) SY87 and (b) BR87. Sources are on reversed profiles. Records are stacks of 19 sweeps with a frequency of $10-42 \mathrm{~Hz}$. Bands of seismic arrivals are observed in both recordings. 
mentary sequence $[18,19]$. More recent reflection data from a profile crossing the Laramie Range approximately $25 \mathrm{~km}$ south of the Cheyenne Belt show no continuous phases from the lower crust and Moho [20]. Gravity data indicate a gradual increase in crustal thickness southward and/or a Proterozoic crust of more intermediate to felsic composition than the Archean block, causing a difference of about $100 \mathrm{mGal}$ across the suture zone [3].

\section{Seismic experiment}

The seismic experiments were designed to record wide-angle reflections mainly from the lower crust and crust-mantle boundary of the
Proterozoic accreted terrane south of the Cheyenne Belt (Fig. 1) over the same depth points where we had normal-incidence reflection data. In two summer field seasons, the University of Wyoming seismic crew acquired data from vibroseis sources and dynamite shots with offsets of up to $126 \mathrm{~km}$. Three densely spaced receiver spreads were deployed. A 48-channel (96 channels in parts of the profile) profile (SY87) with $100 \mathrm{~m}$ group spacing was located in the Laramie Range; two spreads (BR87 and BR89), with 86 and 192 channels with $100 \mathrm{~m}$ group spacing, were deployed in the northernmost Colorado Front Range. Vibroseis sources, consisting of four trucks with up to 21 linear sweeps of $10-42 \mathrm{~Hz}$ per vibrator point (VP), were situated at 54 locations (50 $\mathrm{m}$ spacing) in the Laramie Range and at 64
VP 22

$\mathrm{p}(\mathrm{s} / \mathrm{km})$

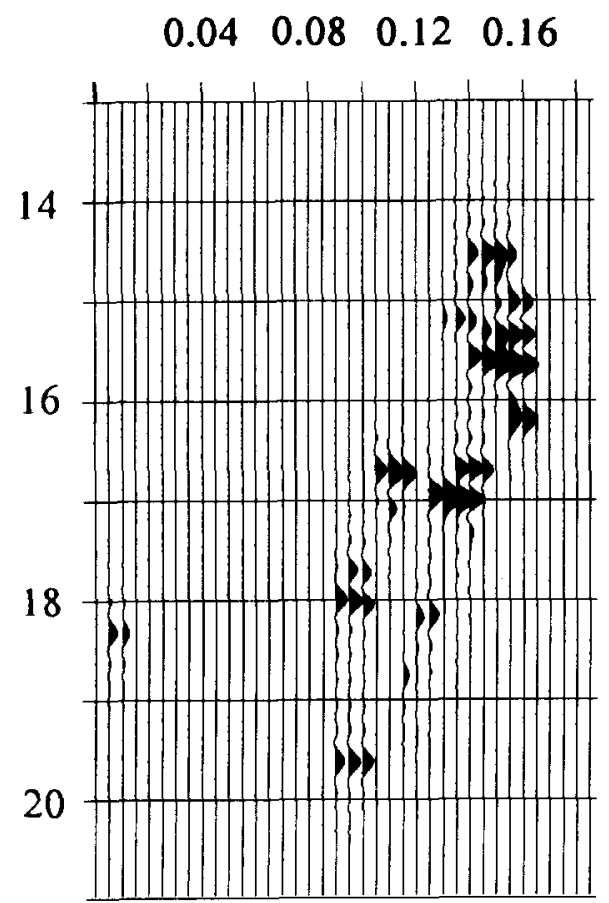

a
VP 143

$$
\mathrm{p}(\mathrm{s} / \mathrm{km})
$$

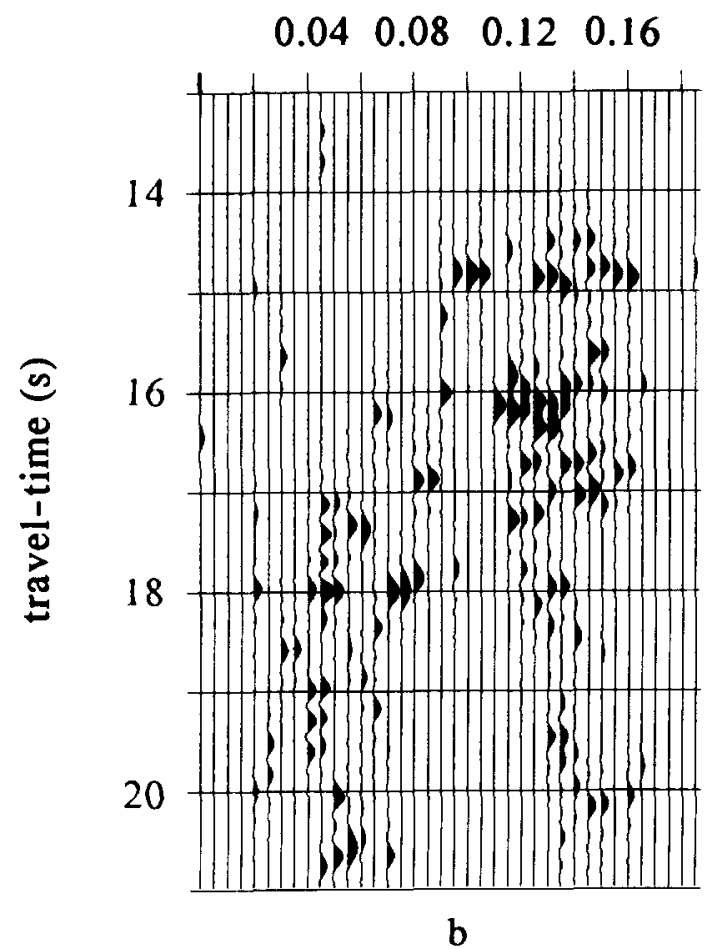

Fig. 3. Coherency-filtered slant stacks $(\tau-p)$ of vibroseis records from (a) VP 22 of profile SY87 and (b) VP 143 of profile BR87. $\tau-p$ arrivals are scattered. High-amplitude events were picked for extremal inversion scheme to estimate depth bounds of reflectors. 


\section{receiver profile BR89}

\section{dynamite record TS}
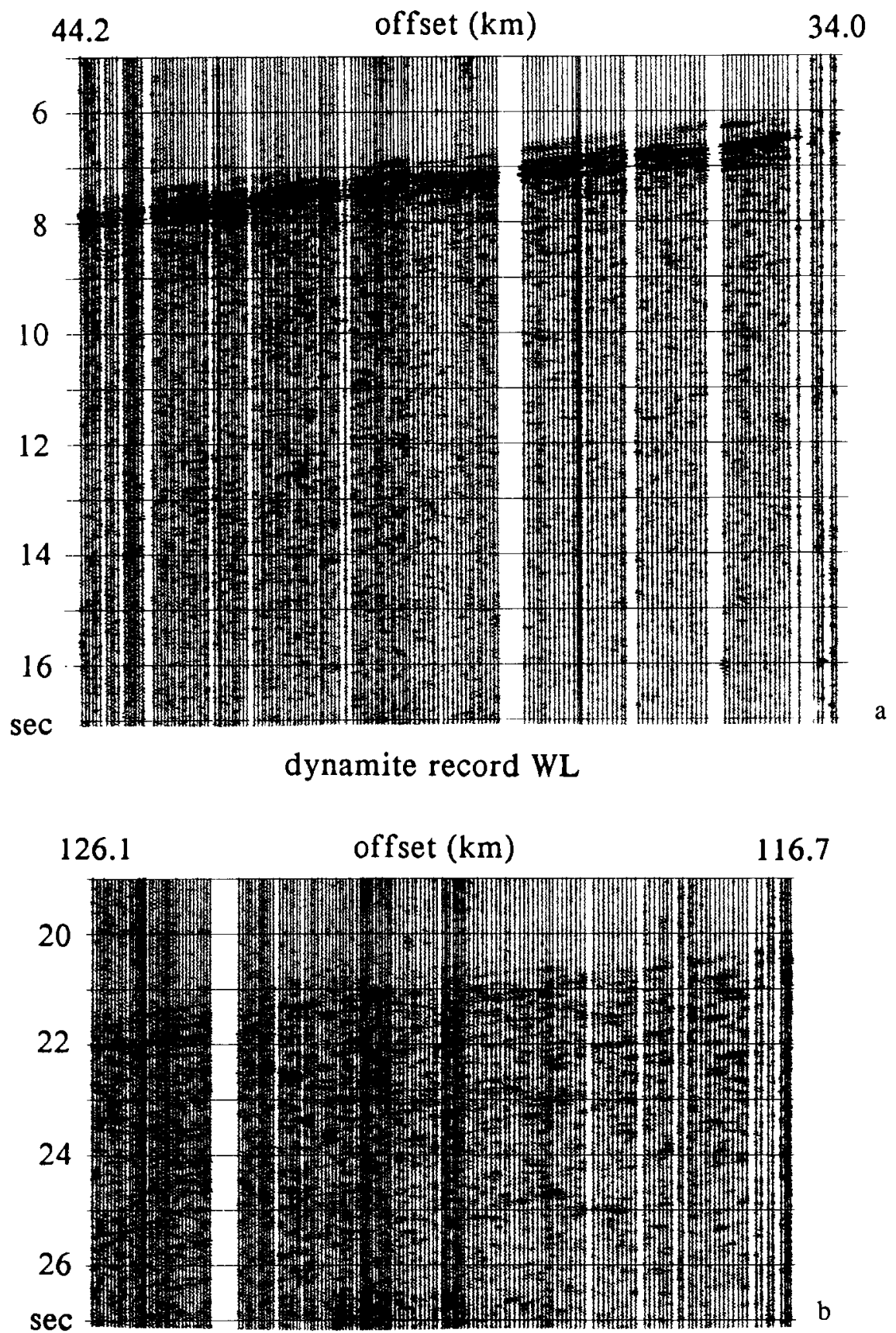

Fig. 4. Dynamite shot records (BR89), vertical component and source location: (a) TS. (b) WL. The shorter offset recording TS contains high-amplitude direct and uppermost crustal P-wave arrivals, but no mid-crustal or lower crustal events and no Moho arrival. The large-offset recording WL shows multicyclic midcrustal and lower crustal P-wave arrivals. Although the WL recording approaches critical distance, it does not contain distinct Moho reflections. 


\section{receiver profile $\mathrm{BR} 89$}

dynamite record WL

\section{transverse}
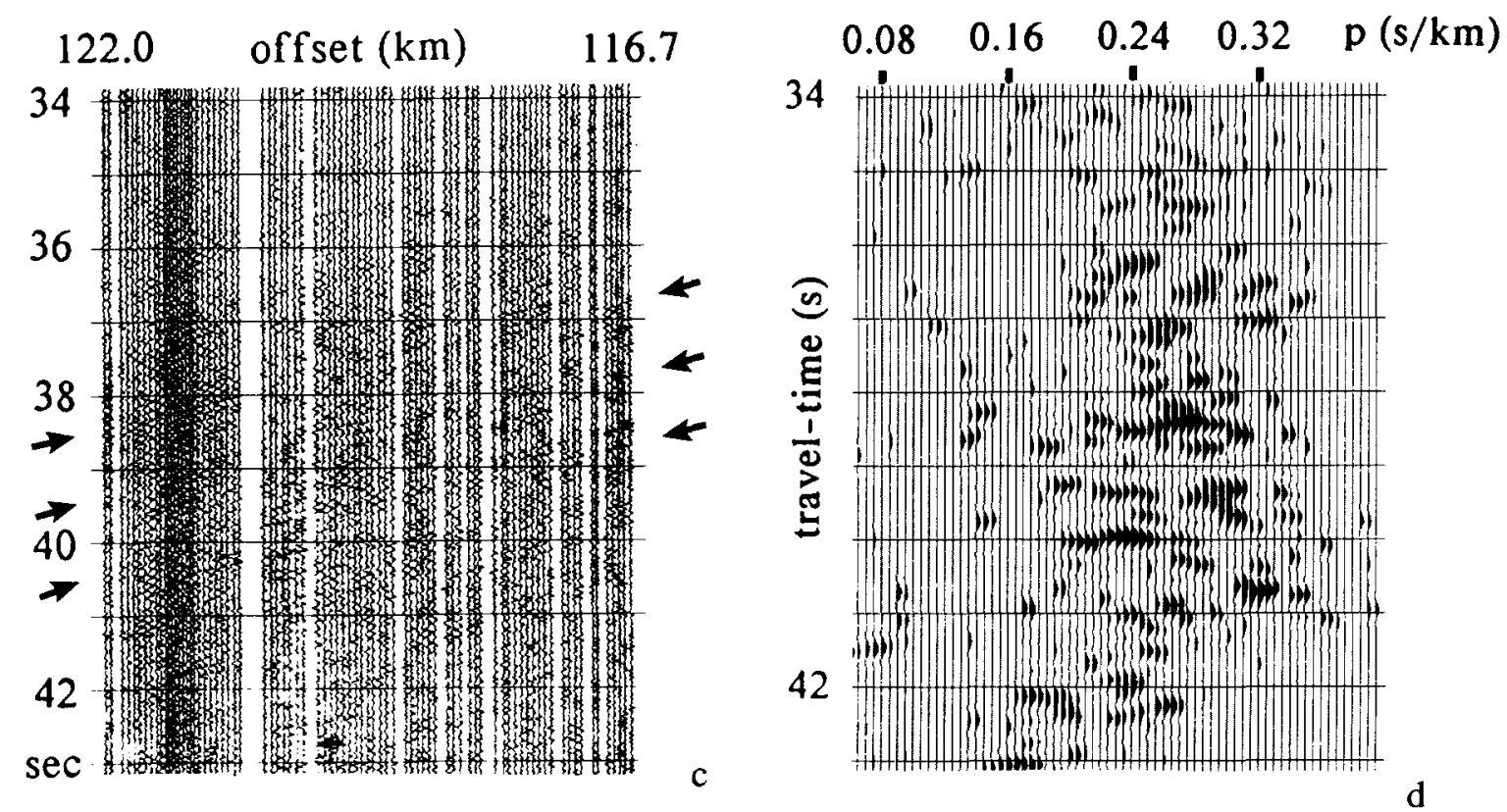

Fig. 4. (c) A $5 \mathrm{~s}$ long band of low-amplitude arrivals beginning at about $35 \mathrm{~s}$ was recorded on the transverse components of shot WL. (d) Their travel time and ray parameter identify them as lower crustal S-wave reflections. The record does not contain a distinct $S$-wave Moho reflection either.

locations (50 $\mathrm{m}$ spacing) in the Front Range to be recorded from profiles BR87 and SY87 respectively. Eight dynamite shots were detonated from the eastern Laramie Range (WL) and the southern Laramie Basin (TL) and were recorded by profile BR89. Horizontal component geophones replaced the vertical component geophones on profile BR89 for some shots to record shear waves.

\section{Processing and data description}

All the vibroseis recordings were corrected for elevation statics, edited, vertically stacked, and bandpass filtered within the sweep frequency. The data quality of the recordings changes among the individual VP gathers, probably due to changes in coupling when sources were moved along the profiles. We slant stacked the data from 27 VPs of profile SY87 and 36 VPs of profile BR87 to obtain an immediate estimate of apparent velocities. A coherency filter applied to individual slant stacks by calculating the semblance [21] aided in the identification of pre-critical and post-critical phases of high-amplitude coherent signals. The coherency-filtered slant stacks for each receiver profile were summed into a single intercept time-ray parameter $(\tau-p)$ gather.

Some vibroseis records contain distinct arrivals (e.g., at $14.5-18.5 \mathrm{~s}$ at the $90 \mathrm{~km}$ offset (Fig. 2a and b)). From their ray parameters and intercept times (Fig. $3 a$ and $b$ ), these phases are identified as first arrivals $\left(\mathrm{P}_{\mathrm{g}}\right)$, a series of mid-crustal refractions and reflections, and multicyclic precritical lower crustal reflections. The peak signal fre- 
quency lies at about $20 \mathrm{~Hz}$. The $\tau-p$ transformation enhances weak-amplitude phases in other record sections.

The seismic sections from the dynamite shots contain series of coherent but short arrivals (Fig. $4 a-c)$. Low- and high-frequency noise was eliminated by a $10-30 \mathrm{~Hz}$ bandpass filter. Peak signal frequencies lie at about $20 \mathrm{~Hz}$. We also slant stacked the shot gathers to enhance phase correlation. The summed $\tau-p$ gather of the two largest shots from WL (maximum $126 \mathrm{~km}$ offset) and TS (maximum $50 \mathrm{~km}$ offset) shows a branch of highamplitude upper crustal arrivals and a branch of scattered mid-crustal and lower crustal reflection arrivals (Fig. $5 \mathrm{c}$ ).

The records of the dynamite shots contain stronger coherent arrivals than the vibroseis data.
First breaks and mid-crustal as well as lower crustal phases arrive within a band of high-amplitude signals on gather WL (Fig. 4b). A high-amplitude Moho reflection is not visible, although the maximum offset of $126 \mathrm{~km}$ is assumed to be close to the critical distance in that area. We calculated a critical distance of $118-125 \mathrm{~km}$ for $\mathrm{P}$-wave Moho arrivals for a $40 \mathrm{~km}$ deep crust with velocities for the upper crust of $5.5 \mathrm{~km} / \mathrm{s}$, for the middle crust of $6.5 \mathrm{~km} / \mathrm{s}$, and a velocity increase for the lower crust of $6.8-7.4 \mathrm{~km} / \mathrm{s}$. A critical arrival from the Moho may be hidden within the multicyclic band of lower crustal arrivals, but transformation into the $\mathrm{t}-p$ domain does not indicate evidence for a distinct Moho reflection either (Fig. 5a-c).

The transverse components of shot gather WL

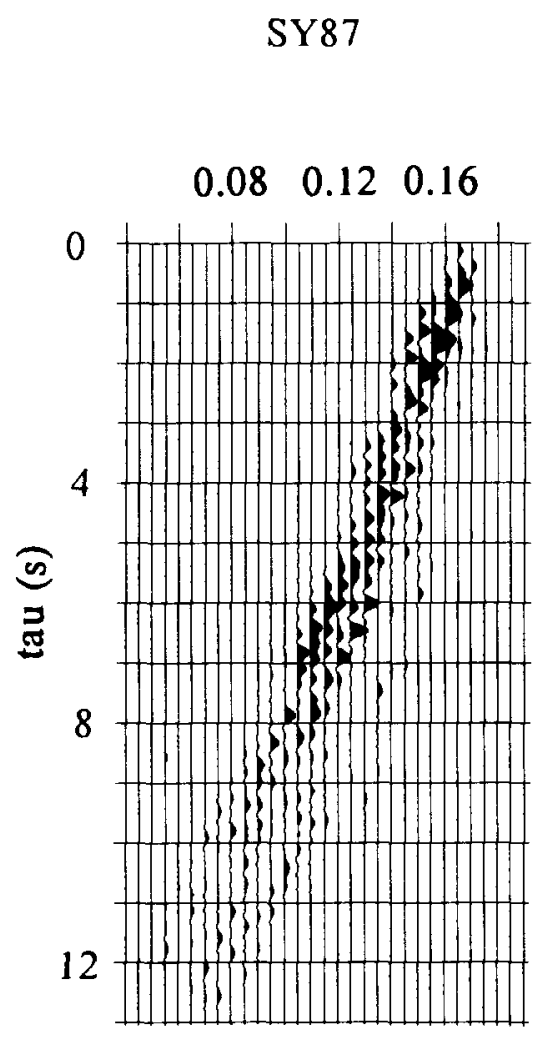

a
BR87

BR89

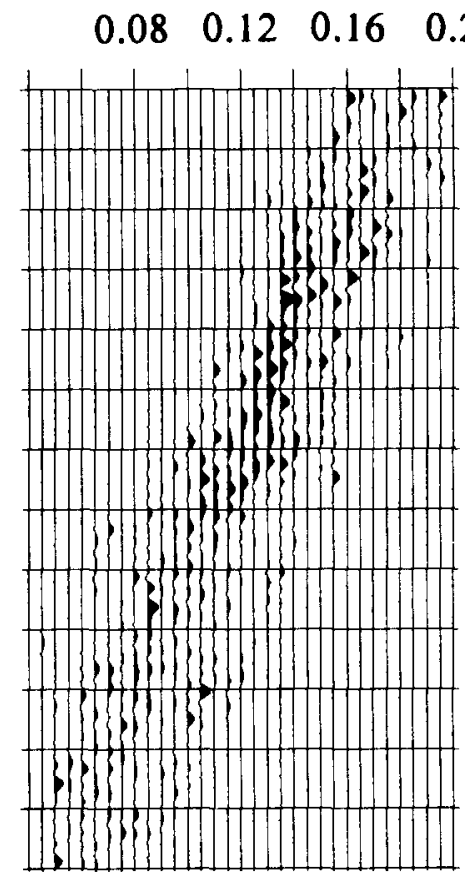

b

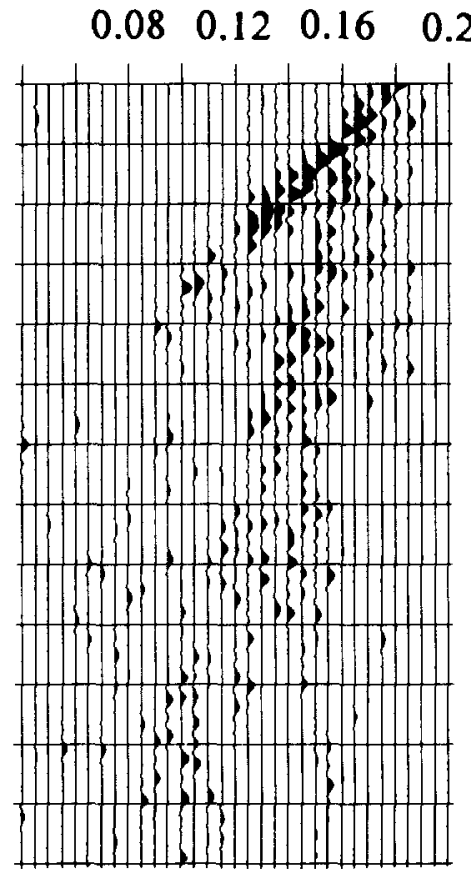

C

Fig. 5. Summed slant stacks of vibroseis records (a) SY87 and (b) BR87, and (c) dynamite record BR89 from source locations TS and WL. High-amplitude events were picked for extremal inversion. Because of better defined arrivals from profile SY 87 within the first $3 \mathrm{~s}(\tau)$ of profile BR89, the assigned uncertainties were only between 0.1 and $0.15 \mathrm{~s}$, resulting in narrower depth bounds in Fig. 7. 
show a broad band of arrivals between 35 and 42 s (Fig. 4c). Their travel time and ray parameter (Fig. 4d) identify them as lower crustal S-wave reflections from the same broad depth range as the corresponding lower crustal $\mathrm{P}$-wave reflections. The record does not contain a distinct S-wave Moho reflection either.

\section{Inverse and forward modelling}

We used picks from P-wave arrivals of individual and summed $\tau-p$ gathers (Fig. $5 \mathrm{a}-\mathrm{c}$ ) to invert for minimum and maximum depth bounds using an extremal inversion method [22,23]. The S-wave dataset was too sparse to perform an inversion reliable enough for an interpretation. The model was parameterized by implementing a stack of layers with constant slownesses with slowness values decreasing with depth. Minimum and maximum depth bounds were calculated for each layer; slownesses are displayed as layer velocities. Be- cause of the narrow horizontal aperture of the shot gathers (between 4 and $9 \mathrm{~km}$ ), the slant stacks consist of accumulations of data points rather than elliptic curves. In a first attempt to invert the data, we picked only a few high-amplitude data points with uncertainties in $\tau$ of $0.1-$ $0.15 \mathrm{~s}$. After successfully modelling these initial picks, we picked more data points with uncertainties in $\tau$ between 0.1 and $0.2 \mathrm{~s}$. The smallest widths of depth bounds could be reached for the dynamite profile BR89 and the vibroseis recordings of profile SY87 (Fig. 6). The summed slant stack of profile BR87 (Fig. 6) contains a few distinct but scattered high-amplitude arrivals, producing wide depth bounds. An interesting result from the $1 \mathrm{D}$ inversion model is the observation of bands of different reflectivity within the sections rather than distinct reflections. The crust appears to consist of an upper and lower crust that is more reflective than the middle crust. The lower crust seems to contain a series of discontinuities. A distinct Moho reflection is not ob-

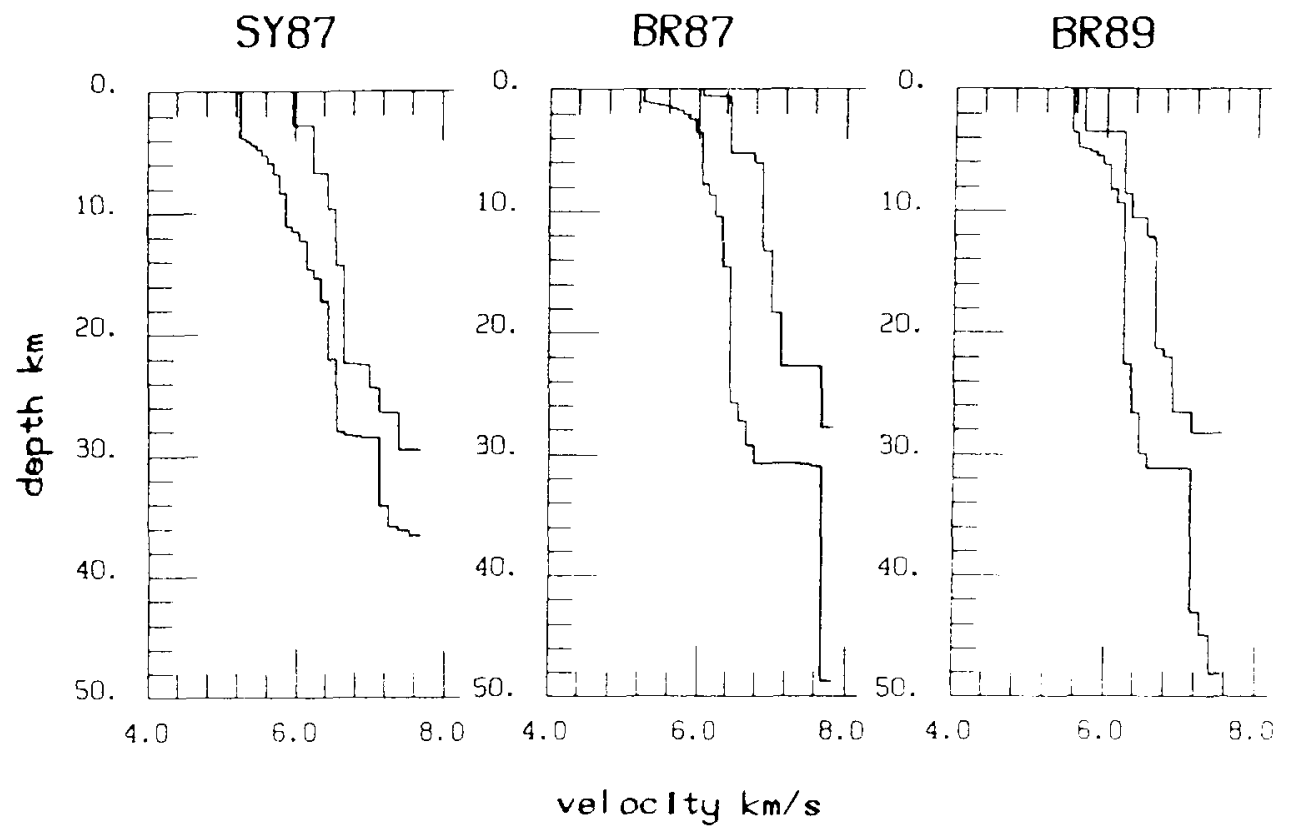

Fig. 6. Results from 1D extremal inversion. Curves represent upper and lower depth bounds. Note the narrower depth bounds of model SY87 and the upper part of BR89, because of smaller uncertainties in $\tau-p$ picks. Depth bound curves contain upper crustal discontinuities down to about $11 \mathrm{~km}$, and a series of lower crustal discontinuities between the 22 and $35 \mathrm{~km}$ depths. A distinct Moho is not observed, and therefore the uncertainties in crustal depth are large. There is evidence of high velocity of $>7 \mathrm{~km} / \mathrm{s}$ for the lowermost $8-10 \mathrm{~km}$. 
served, not even in the large-distance recording of shot WL. The lowermost reflections are best modelled with discontinuities at depths of 25-40 $\mathrm{km}$.

Lower crustal models chosen for the reflectivity modelling method [24] include a transitional zone from the 25 to the $40 \mathrm{~km}$ depth consisting of layers of alternating low and high velocities (Fig. $7 \mathrm{a}-\mathrm{d})$. This type of model is chosen to represent our observations in which we identify a broad band of lower crustal reflections at large offsets

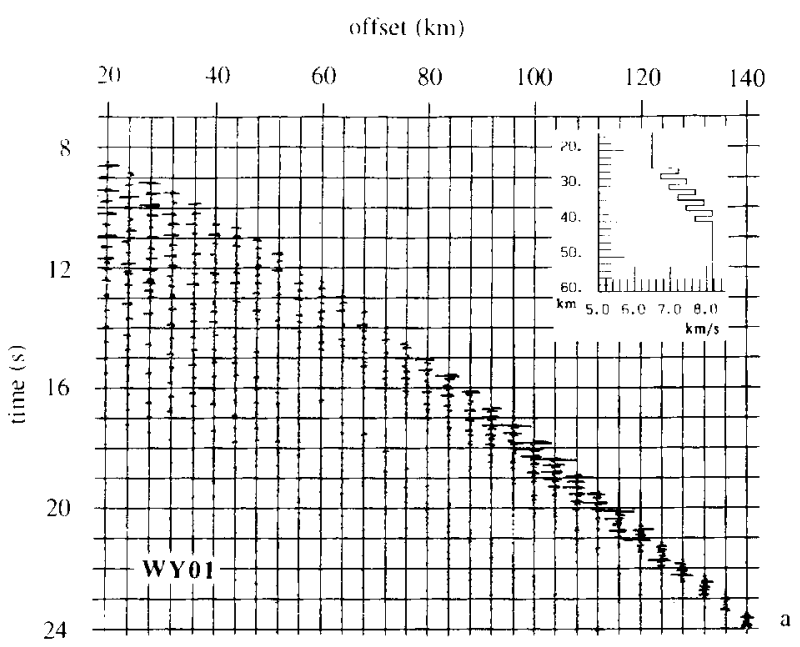

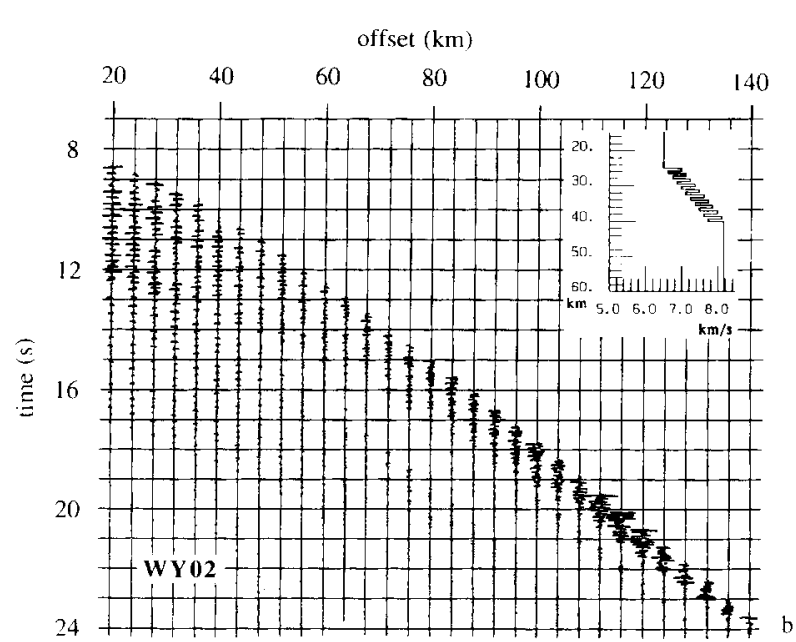

but not at pre-critical and normal-incidence [20] geometries. This type of model also represents observations of exposed lower crust of Phanerozoic and Proterozoic arcs consisting of differentiated layered plutonic complexes ranging from ultramafic to felsic in composition [25-27]. The thickness of the individual layers within the transitional zone of our models varies between $0.3 \mathrm{~km}$ (about one wavelength) and $1.5 \mathrm{~km}$. Velocities range from $6.5 \mathrm{~km}$ on top of the zone to an upper mantle velocity of $8.2 \mathrm{~km} / \mathrm{s}$ at the base. The
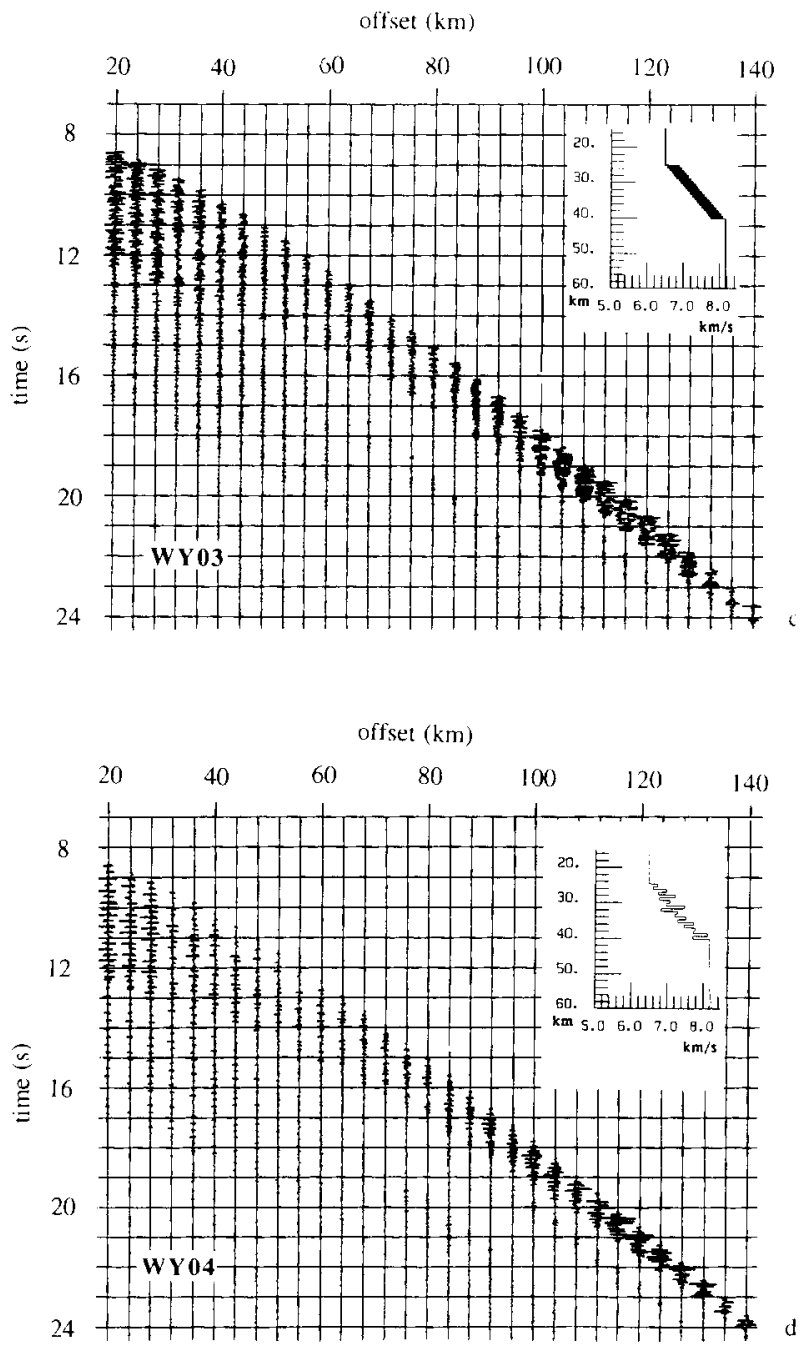

Fig. 7. (a-d) Synthetic seismograms with corresponding velocity-depth models by using the reflectivity method. Lower crustal layering with individual layer thicknesses of $0.3-1.5 \mathrm{~km}$ approximates intermediate-felsic interlayering as observed in the exposed cross sections. 
velocity difference between layers lies between 0.4 and $0.5 \mathrm{~km} / \mathrm{s}$, corresponding to observed velocity contrasts between noritic-anorthositiccharnockitic and garnet- and pyroxene-granulitic-eclogitic rocks at lower crustal depths and pressure [28-32]. Laboratory experiments at lower crustal pressures of up to 10 kbar show P-wave velocities for garnet- and pyroxene-granulites and anorthosites of about $6.7-7.4 \mathrm{~km} / \mathrm{s}$ and for eclogites of more than $7.6 \mathrm{~km} / \mathrm{s}$, and often exceeding $8 \mathrm{~km} / \mathrm{s}$ [28-32]. One of the models (Fig. 7d) consists of layering with random velocity variations. Such randomness might be more likely to exist in the real earth than evenly incremented velocity differences. The synthetic seismograms show similar features in all four models, such as a $0.8-1.3 \mathrm{~s}$ broad band of high-amplitude arrivals at the critical angle (offset of $120-130 \mathrm{~km}$ ) and a $\sim 2 \mathrm{~s}$ broad band of reflections at the $80-90 \mathrm{~km}$ offset. Corresponding reflection bands in the real data at these offsets are 2-4 s broader compared to the synthetic data, possibly due to coda and multiples. The random velocity model (Fig. 7d) illustrates the best match with the observed data, because it contains a short strong amplitude band of arrivals, as observed in parts of the large-offset (maximum $130 \mathrm{~km}$ ) dynamite recording, and in the pre-critical $(85-100 \mathrm{~km})$ vibroseis recordings. The broad band of scattered arrivals of the observed data might be due to small-scale random lateral heterogeneities in the lower crust creating a scattering effect in the wide-angle data $[33,34]$. Calculated maximum amplitudes at the $30-40 \mathrm{~km}$ offset are about $16 \mathrm{db}$ smaller than the maximum amplitudes at critical distance, and they are spread over a broad band of $4 \mathrm{~s}$. Slant stacking is usually a valuable process in enhancing such coherent low-amplitude arrivals, but there is no evidence for pre-critical lower crustal arrivals in dynamite shot recording TS.

\section{Discussion}

Previous seismic normal-incidence and wideangle reflection and refraction data as well as our data show that the Proterozoic lower crust in southeastern Wyoming is reflective at large source-receiver offsets but not at pre-critical or near-vertical [20] distances. We do not, however, observe distinct $\mathrm{P}$-wave and $\mathrm{S}$-wave Moho reflections, although we reach the critical distance of approximately $120 \mathrm{~km}$ for Moho reflections from a presumed $40 \mathrm{~km}$ deep crust, depending on the velocity distribution, particularily in the lowermost crust. Our observation is consistent with earlier refraction surveys in northern Colorado and southeastern Wyoming $[14,15]$. These earlier studies reveal no critical Moho reflections from the area just south of the Archean province, in contrast to high-amplitude wide-angle reflections from the Archean in Wyoming and the Proterozoic in northern-central Colorado.

The depth bounds derived from 1D inversion indicate a steady increase in lower crustal velocities, ranging from $6.5 \mathrm{~km} / \mathrm{s}$ at the $25 \mathrm{~km}$ depth to about $7.5 \mathrm{~km} / \mathrm{s}$ at the lowest observable depths. We modelled a sequence of alternating low- and high-velocity layers with velocities ranging from 6.5 to $7.5 \mathrm{~km} / \mathrm{s}$ between the 25 and $37 \mathrm{~km}$ depths. Models of a layered or laminated lower crust and crust-mantle transition zone have been described by several authors [35-37] but seldom with such a high average velocity in the lower crust and a total lack of a critical Moho reflection. If the Proterozoic crust is considered to be the relict of an accreted island arc as the metavolcanic surface rocks suggest $[5,6]$, a possible upper and mid-crustal bulk composition would consist of metavolcanic rocks and felsic plutons. Exposures of island arc middle crust (e.g., in northern Pakistan (Kohistan)), are dominated by migmatites and tonalitic batholiths with increasing grade of metamorphism from amphibolite to granulite facies with depth [26,27]. The lower crust, which is highly reflective at wide-angle distances, may contain rocks of more mafic to ultramafic composition interlayered with charnockitic and anorthositic complexes. The metamorphic grade of layered sequences in island arc complexes increases with depth from low-pressure to high-pressure granulite and eclogite facies [26]. Examples of such interlayered lower crustal island arc sequences are exposed in northern Pakistan [27,38] and New Zealand [39]. Xenoliths from the lower crust of the Aleutian arc are of 
ultramafic to intermediate composition [40]. Our reflectivity models approximate a sequence of interlayered rock types in which the velocities lie within the range of the observed values for anorthosites, charnockites, garnet-granulites and eclogites [29-32]. Hamilton [25,26] argues that the Moho in magmatic arcs is either a zone of intercalated mafic and ultramafic rocks rather than a sharp boundary, or a phase transition from granulite to eclogite facies. Both increasing metamorphic grade and a gradual increase from mafic to ultramafic components with depth cause an increase in rock velocities to those close to upper mantle velocities, explaining the lack of impedance contrasts necessary to generate critical reflections.

The lack of distinct Moho reflections seems to be a common observation in other Proterozoic accreted arc complexes. For instance, reflection data from the Precambrian midcontinent of the Great Lakes region [41] show features similar to our wide-angle data. In the Great Lakes region, a highly reflective lower crustal zone and a lack of a distinct Moho reflection is observed beneath an early Proterozoic island arc terrane bounded by two Archean blocks.

The lack of Moho reflections does not permit us to verify the crustal model of southwest Wyoming derived from gravity and low-resolution refraction data $[3,15]$ in which the crust deepens from the Archean craton to the Proterozoic accreted crust. Although the inversion and forward modelling results might be biased to a small degree by a dipping structure, our data provide an estimate of crustal composition and formation of an early Proterozoic island arc complex whose compositional character might have been preserved through time.

\section{Conclusions}

Seismic wide-angle data for the Proterozoic crust south of the boundary against the Archean Wyoming Province in southeastern Wyoming indicate a moderately reflective lower crust at large (critical) offsets, whereas previous normal-incidence reflection data lack events from the lower crust. Velocity-depth models derived from midcrustal to lower crustal P-wave arrivals of largeoffset $(85-126 \mathrm{~km})$ vibroseis and dynamite recordings show that the lower crust may consist of a 10-12 km thick zone of alternating high and low velocities. The lower crustal layer P-wave velocities range from 6.5 to $7.5 \mathrm{~km} / \mathrm{s}$. The average lower crustal velocity of $6.9 \mathrm{~km} / \mathrm{s}$ suggests a predominantly mafic composition with interlayered intermediate components generating impedance contrasts that cause observable amplitudes from reflections at large offsets but not at clearly pre-critical and near-vertical distances. Our model resembles observations from the exposed lower crust of magmatic arc complexes that show interlayered sequences of gabbroic to ultramafic rocks with more felsic anorthositic and charnockitic rocks. Despite an increased lower crustal reflectivity in the wide-angle data, it is striking that we do not observe distinct Moho reflections in our wide-angle recordings, not even at the large distance of $126 \mathrm{~km}$. This is consistent with the lack of Moho reflections in previous and more recent normal-incidence reflection profilings. A gradational boundary with predominantly olivine-free norites and gabbros above and ultramafic rocks below, or a transitional phase change from highpressure granulite to eclogite facies [25,41], might explain the lack of Moho reflections. The loss of Moho arrivals in crossing from Archean into Proterozoic crust is observed at other boundaries too [42], indicating a major difference in the two types of crust. Although the data coverage is sparse, our observations are consistent with the interpretation that the Proterozoic terrane south of the Cheyenne Belt might be an accreted magmatic arc which predominantly consists of complexes of highly fractionated island arc products causing seismic wide-angle reflections from the lower crust but not the Moho.

\section{Acknowledgements}

Thanks to the University of Wyoming seismic crew for their work during the summer field seasons. Rob Hawman's original motivation for conducting this experiment is very much appreci- 
ated. Art Snoke provided critical comments. This project was supported by NSF grant EAR8708597.

\section{References}

[1] F.A. Hills and R.L. Armstrong, Geochronology of Precambrian rocks in the Laramie Range and implications for the tectonic framework of Precambrian southern Wyoming, Precambrian Res. 1, 213-225, 1974.

[2] K.C. Condie, Plate-tectonics model for Proterozoic continental accretion in the southwestern United States, Geology 10, 37-42, 1982.

[3] R.A. Johnson, K.E. Karlstrom, S.B. Smithson and R.S. Houston, Gravity profiles across the Cheyenne Belt, a Precambrian crustal suture in southeastern Wyoming, $\mathrm{J}$. Geodyn. 1, 445-472, 1984.

[4] E.M. Duebendorfer and R.S. Houston, Kinematic history of the Cheyenne belt, Medicine Bow Mountains, southeastern Wyoming, Geology 14, 171-174, 1986.

[5] E.M. Duebendorfer and R.S. Houston, Proterozoic accretionary tectonics at the southern margin of the Archean Wyoming craton, Geol. Soc. Am. Bull. 98, 554$568,1987$.

[6] R.S. Houston, E.M. Duebendorfer, K.E. Karlstrom and W.R. Premo, A review of the geology and structure of the Cheyenne belt and Proterozoic rocks of southern Wyoming, in: Proterozoic Geology of the Southern Rocky Mountains, J.A. Grambling and B.J. Tewksbury, eds., Geol. Soc. Am. Spec. Pap. 235, 1-12, 1989.

[7] F.A. Hills, P.W. Gast, R.S. Houston and I.G. Swainbank, Precambrian geochronology of the Medicine Bow Mountains, southeastern Wyoming, Geol. Soc. Am. Bull. 79, 1757-1784, 1968.

[8] K.E. Karlstrom and R.S. Houston, The Cheyenne belt: Analysis of a Proterozoic suture in southern Wyoming, Precambrian Res. 25, 415-446, 1984.

[9] K.E. Karlstrom, A.J. Flurkey and R.S. Houston, Stratigraphy and depositional setting of Proterozoic metasedimentary rocks in southeastern Wyoming: Record of an Early Proterozoic Atlantic-type cratonic margin, Geol. Soc. Am. Bull. 94, 1257-1294, 1983.

[10] Z.E. Peterman, C.E. Hedge and W.A. Braddock, Age of Precambrian events in the northeastern Front Range, Colorado, J. Geophys. Res. 73, 2277-2296, 1968.

[11] W.R. Premo and W.R. Van Schmus, Zircon geochronology of Precambrian rocks in southeastern Wyoming and northern Colorado, in: Proterozoic Geology of the Southern Rocky Mountains, J.A. Grambling and B.J. Tewksbury, eds., Geol. Soc. Am. Spec. Pap. 235, 13-32, 1989.

[12] D.J. Geist, C.D. Frost, A. Kolker and B.R. Frost, A geochemical study of magmatism across a major terrane boundary: $\mathrm{Sr}$ and $\mathrm{Nd}$ isotopes in Proterozoic granitoids of the southern Laramie Range, Wyoming, J. Geol. 97, 331-342, 1989.
[13] W.H. Jackson, S.W. Steward and L.C. Pakiser, Crustal structure in eastern Colorado from seismic-refraction measurements, J. Geophys. Res. 68, 5767-5776, 1963.

[14] W.H. Jackson and L.C. Pakiser, Seismic study of crustal structure in the southern Rocky Mountains, U.S. Geol. Surv. Prof. Pap. 525D, 85-92, 1965.

[15] C. Prodehl and L.C. Pakiser, Crustal structure of the southern Rocky Mountains from seismic measurements, Geol. Soc. Am. Bull. 91, 147-155, 1980.

[16] R.W. Allmendinger, J.A. Brewer, L.D. Brown, S. Kaufman, J.E. Oliver and R.S. Houston, COCORP profiling across the Rocky Mountain Front in southern Wyoming, part 2: Precambrian basement structure and its influence on Laramide deformation, Geol. Soc. Am. Bull. 93, 12531263, 1982.

[17] J.A. Brewer, R.W. Allmendinger, L.D. Brown, J.E. Oliver and S. Kaufman, COCORP profiling across the Rocky Mountain Front in southern Wyoming, part 1: Laramie structure, Geol. Soc. Am. Bull. 93, 1242-1252, 1982.

[18] R.A. Johnson and S.B. Smithson, Thrust faulting in the Laramie Mountains, Wyoming, from reanalysis of $\mathrm{CO}$ CORP data, Geology 13, 534-537, 1985.

[19] R.A. Johnson and S.B. Smithson, Interpretive processing of crustal seismic reflection data: examples from Laramie Range COCORP data, in: Reflection Seismology: A Global Perspective, M. Barazangi and L. Brown, eds., AGU Geodyn. Ser. 13, 197-208, 1986.

[20] M.A. Speece, B.R. Frost and S.B. Smithson, Precambrian basement structure and Laramide deformation revealed by seismic reflection profiling in the Laramie Mountains, Wyoming, Tectonics 13, 354-366, 1994.

[21] P.L. Stoffa, P. Buhl, J.B. Diebold and F. Wenzel, Direct mapping of seismic data to the domain of intercept time and ray parameter: A plane wave decomposition, Geophysics 46, 255-267, 1981.

[22] E.N. Bessonova, V.M. Fishman, V.Z. Ryaboyi and G.A. Sitnikova, The tau method for inversion of travel times-I. Deep seismic sounding data, Geophys. J.R. Astron. Soc. 36, 377-398, 1974.

[23] R.B. Hawman and R.A. Phinney, Analysis of sparse wide-angle reflection data in the $t(p)$ domain, Bull. Seismol. Soc. Am. 81, 202-221, 1991.

[24] K. Fuchs and G. Mueller, Computation of synthetic seismograms with the reflectivity method and comparison with observations, Geophys. J.R. Astron. Soc. 23, 417-433, 1971.

[25] W.B. Hamilton, Crustal evolution by arc magmatism, Philos. Trans. R. Soc. London A301, 279-291, 1981.

[26] W.B. Hamilton, Plate tectonics and island arcs, Geol. Soc. Am. Bull. 100, 1503-1527, 1988.

[27] J.P. Bard, Metamorphism of an obducted island arc: example of the Kohistan sequence (Pakistan) in the Himalayan collided range, Earth Planet. Sci. Lett. 65, 133$144,1983$.

[28] F. Birch, The velocity of compressional waves in rocks to 10 kilobars, 2, J. Geophys. Res. 66, 2199-2224, 1961.

[29] M.H. Manghnani, R. Ramananantoandro and S.P. Clark, 
Jr., Compressional and shear wave velocities in granulite facies rocks and eclogites to $10 \mathrm{kbar}$, J. Geophys. Res. 70 , 5427-5446, 1974.

[30] N.I. Christensen and D.M. Fountain, Constitution of the lower continental crust based on experimental studies of seismic velocities in granulite, Geol. Soc. Am. Bull. 86, 227-236, 1975.

[31] I. Jackson and R.J. Arculus, Laboratory wave velocity measurements on lower crustal xenoliths from Calcutteroo, South Australia, Tectonophysics 101, 185-197, 1984.

[32] D.M. Fountain, M.H. Salisbury and J. Percival, Seismic structure of the continental crust based on rock velocity measurements from the Kapuskasing uplift, J. Geophys. Res. 95, 1167-1186, 1990.

[33] B.S. Gibson and A.R. Levander, Lower crustal reflectivity patterns in wide-angle seismic recordings, Geophys. Res. Lett. 15, 617-620, 1988.

[34] A.R. Levander and B.S. Gibson, Wide-angle seismic reflections from two-dimensional random target zones, J. Geophys. Res. 96, 10233-10250, 1991.

[35] L.D. Hale and G.A. Thompson, The seismic reflection character of the continental Mohorovicic Discontinuity, J. Geophys. Res. 87, 4625-4635, 1982.

[36] R. Meissner, Twenty years of deep seismic reflection profiling in Germany-a contribution to our knowledge of the nature of the lower Variscan crust, in: The Nature of the Lower Continental Crust, J.B. Dawson, D.A. Carswell, J. Hall and K.H. Wedepohl, eds., Geol. Soc. London Spec. Publ. 24, 1-10, 1986.

[37] K.-J. Sandmeier and F. Wenzel, Lower crustal petrology from wide-angle $\mathrm{P}$ - and S-wave measurements in the Black Forest, Tectonophysics 173, 495-505, 1990.

[38] M.P. Coward, M.Q. Jan, D. Rex, J. Tarney, M. Thirlwall and B.F. Windley, Geo-tectonic framework of the Himalaya of N Pakistan, J. Geol. Soc. London 139, 299-308, 1982.

[39] J.M. Mattinson, D.L. Kimbrough and J.Y. Bradshaw, Western Fiordland orthogneiss-Early Cretaceous arc magmatism and granulite facies metamorphism, New Zealand, Contrib. Mineral. Petrol. 92, 383-392, 1986.

[40] S. Mahlburg Kay and R.W. Kay, Role of crystal cumulates and the oceanic crust in the formation of the lower crust of the Aleutian arc, Geology 13, 461-464, 1985.

[41] S.B. Smithson, Contrasting types of lower crust, in: Properties and Processes of Earth's Lower Crust, R.F. Mereu, St. Mueller and D.M. Fountain, eds., AGU Geophys. Monogr. 51, 53-63, 1989.

[42] W.F. Cannon, M.W. Lee, W.J. Hinze, K.J. Schulz and A.G. Green, Deep crustal structure of the Precambrian basement beneath northern Lake Michigan, midcontinent North America, Geology 19, 207-210, 1991. 